\title{
Fertility following treatment of high-grade malignant bone and soft tissue tumors in young adults
}

\author{
MANABU HOSHI, MASATSUGU TAKAMI, MAKOTO IEGUCHI, MASANARI AONO, \\ JUN TAKADA, NAOTO OEBISU, TADASHI IWAI and HIROAKI NAKAMURA \\ Department of Orthopedic Surgery, Osaka City University Graduate School of Medicine, Osaka 545-8585, Japan
}

Received July 28, 2014; Accepted November 18, 2014

DOI: $10.3892 / \mathrm{mco} .2014 .474$

\begin{abstract}
This study was conducted to investigate marriage and fertility in long-term survivors with high-grade bone and soft tissue tumors following chemotherapy. We reviewed issues related to fertility in 47 patients $(24$ men and 23 women) who had survived for $>5$ years. The median age at diagnosis was $18.0 \pm 8.9$ years and the mean duration of follow-up 11.0 years. We investigated the proportions of married subjects (number of married/total number of subjects) and fertile subjects (number who had fathered or conceived offspring/total number of subjects), the interval between first delivery and last chemotherapy, type of delivery, congenital deformities in the offspring and the association between cumulative dose of chemotherapeutic agents and subsequent reproduction. The final proportions of married and fertile subjects following sarcoma treatment were $36.2 \%$ (17/47) and $29.8 \%$ (14/47), respectively. Two subjects had fathered and 8 had conceived a total of 15 offspring. The proportion of fertile men was significantly lower compared to that of women. The mean interval between the last chemotherapy and the first delivery was 9.5 years. Of the 10 first births, 6 were normal transvaginal deliveries and 4 were caesarean sections (1 was a medical termination due to lung metastases, 1 was due to infected amniotic fluid caused by uterine myomas and 2 were performed due to abnormal rotation of the fetus). No offspring presented with congenital deformities. Fertile men had received smaller cumulative chemotherapeutic agent doses, particularly of ifosfamide, compared to those who had not fathered any offspring. In conclusion, infertility occurs more frequently in men compared to women following intensive chemotherapy. All the patients should be offered counseling regarding the potential risk of infertility prior to cancer treatment.
\end{abstract}

Correspondence to: Dr Manabu Hoshi, Department of Orthopedic Surgery, Osaka City University Graduate School of Medicine, 1-4-3 Asahi-Machi, Abeno-Ku, Osaka 545-8585, Japan

E-mail: hoshi@med.osaka-cu.ac.jp

Key words: marriage, fertility, childbirth, chemotherapy, sarcoma

\section{Introduction}

Over the last few years, with the advances in multidisciplinary therapy, including neoadjuvant chemotherapy $(1,2)$, radiation therapy (3) and limb-preserving surgery $(4,5)$, the prognosis of high-grade bone and soft tissue tumors has markedly improved, with a corresponding increase in the number of long-term survivors. This increase has generated new problems in the form of latent treatment-related adverse effects (6). Although several types of cancer occur predominantly in the elderly, a number of cancers arise prior to or during the reproductive age. For example, high-grade bone and soft tissue tumors, such as osteosarcoma, Ewing's sarcoma and synovial sarcoma, most commonly occur in adolescents and young adults. Similar to healthy individuals, young survivors of such cancers would expect to get married and parent their own offspring (7).

Amputation or limb-preserving surgery are now routinely performed on patients with high-grade bone and soft tissue tumors arising in the extremities. Limb-preserving surgery with a wide margin has achieved positive outcomes; however, loss of limb function remains an unsolved problem. Marriage is an important goal for patients, from the physical as well as the psychological perspective (8). However, chemotherapeutic agents may cause gonadal toxicity and long-term impairment of fertility, with infertility being one of the major long-term adverse effects of chemotherapy. A number of studies have addressed gonadal toxicity following chemotherapy for hematological malignancies and testicular and breast cancers (9-11); however, only a limited number of studies have addressed marriage and fertility in long-term survivors of high-grade bone and soft tissue sarcomas (12-15). In this study, we aimed to investigate specific issues, such as the effect of the treatment of high-grade bone and soft tissue tumor on marriage and fertility of long-term survivors, whether it is safe for these patients to father or conceive offspring, the optimal interval between the completion of the last chemotherapy and conception and whether the cumulative dose of chemotherapeutic agents are associated with subsequent fertility.

\section{Materials and methods}

Patients. Between September, 1985 and December, 2013, 272 patients aged $<40$ years at diagnosis were treated for high-grade bone and soft tissue tumors at Osaka City 
University Hospital (Osaka, Japan). The inclusion criteria for this study were male or female patients who had been diagnosed with high-grade malignant bone or soft tissue tumors, received chemotherapy and survived for $>5$ years after the initial treatment; a total of 47 patients fulfilled these criteria. The patients comprised 24 men and 23 women, with a median age at diagnosis \pm standard deviation (SD) of $18.0 \pm 8.9$ years (range, 4-40 years). The median age \pm SD at the last follow-up was $33.0 \pm 9.5$ years. The mean duration of the follow-up was 11.0 years (range, 5.0-28.0 years). The mean interval from the last chemotherapy to the last follow-up was 10.1 years (range, 0.1-27.3 years).

The study protocol was approved by the Institutional Ethics Review Board of Osaka City University Graduate School of Medicine.

Treatment. In this series, the treatment protocol for patients with high-grade bone and soft tissue sarcomas consisted of preoperative chemotherapy, wide resection and postoperative chemotherapy. Various surgical procedures, including amputation, rotationplasty and reconstruction with tumor prostheses, were performed. When the only option was amputation, this was performed after providing a full explanation and receiving the patient's informed consent.

The chemotherapeutic protocols for high-grade osteosarcoma were as follows: Between 1985 and 1996 (16), chemotherapy was administered preoperatively for an average of 3.5 months and postoperatively for 7.2 months. Adriamycin (DOX) was administered intravenously (i.v.) at a dose of $40-60 \mathrm{mg} / \mathrm{m}^{2}$ every $2-3$ weeks. Methotrexate (MTX) was administered i.v. at a dose of $200-300 \mathrm{mg} / \mathrm{kg}$ every 2 weeks. Cisplatin (CDDP) was administered i.v. at a dose of $100-130 \mathrm{mg} / \mathrm{m}^{2}$ every 3 weeks. The patients were divided into six groups according to the protocols of preoperative chemotherapy they had received: Group 1 had received DOX-DOX-MTX-MTX, group 2 DOX-CDDP-DOX, group 3 CDDP-CDDP-MTX-MTX, group 4 CDDP-CDDP-CDDP, group 5 MTX-MTX-CDDP-CDDP and group 6 MTX-MTXCDDP+DOX-MTX-MTX-CDDP-DOX. Postoperative chemotherapy was repeated twice, using the same protocols as for the preoperative chemotherapy.

Between 1997 and 2004, intensive doses of chemotherapy were administered according to the OOS-D protocol (17), which was based on the T10 and T12 protocols with modifications (1,2). Two cycles of DOX $90 \mathrm{mg} / \mathrm{m}^{2}$ plus CDDP $120 \mathrm{mg} / \mathrm{m}^{2}$ and ifosfamide (IFM) $15 \mathrm{~g} / \mathrm{m}^{2}$ were administered as neoadjuvant chemotherapy and two cycles of DOX/CDDP and IFM plus two cycles of high-dose MTX (10-12 $\left.\mathrm{g} / \mathrm{m}^{2}\right)$ postoperatively.

Between 2005 and 2013, caffeine-assisted chemotherapy was introduced according to the K2 protocol (18).

Patients with Ewing's sarcoma received high-dose intensive chemotherapy, according to the European Ewing Tumor Working Initiative of National Groups 1999 protocol, with modifications (19). The six cycles of preoperative chemotherapy comprised vincristine (VCR; $1.4 \mathrm{mg} / \mathrm{m}^{2} /$ day; day 1 ), IFM (3.0 g/m²/day; days 1-3), DOX (20 mg/m²/day; days 1-3) and etoposide (ETP; $150 \mathrm{mg} / \mathrm{m}^{2} /$ day; days 1-3). Postoperatively, the patients received one cycle of VCR $\left(1.5 \mathrm{mg} / \mathrm{m}^{2}\right.$; day 1$)$, cyclophosphamide $\left(1.5 \mathrm{~g} / \mathrm{m}^{2}\right.$; day 1$)$ and actinomycin-D
(0.7 mg/m² ; days 1-2). Subsequently, following pretreatment with busulfan (4 mg/kg/day; days 1-4) and L-phenylalanine mustard (70 $\mathrm{mg} / \mathrm{m}^{2}$; days $1-3$ ), the patients also received adjuvant peripheral blood stem cell transplantation.

Patients with high-grade soft tissue sarcomas received DOX and IFM-based chemotherapy. The preoperative chemotherapy consisted of DOX (30 mg/m² i.v.; days 1-2) and IFM ( $2 \mathrm{~g} / \mathrm{m}^{2}$ i.v.; days $\left.1-5\right)$ repeated three times at 3-week intervals. Following tumor resection, two courses of the same regimen administered preoperatively were given at 3 -week intervals (20).

For patients with relapse in pulmonary or other sites, second-line chemotherapy comprised IFM $\left(1,800 \mathrm{mg} / \mathrm{m}^{2} /\right.$ day; days $0-4)$, carboplatin (400 $\mathrm{mg} / \mathrm{m}^{2} /$ day; days $\left.0-1\right)$ and ETP (100 mg/m²/day; days 0-4) with some modifications (21).

Classification by marriage. The proportion of married subjects was defined as number of married/total number of subjects and was investigated to clarify whether treatment exerted an effect on achieving marriage. To assess the true effect of treatment, the 'true marriage proportion' was calculated from the difference in the proportion of patients already married at presentation and at the final follow-up. The associations between the proportion of married patients and gender (male vs. female), age [ $<20$ vs. $\geq 20$ years (in Japan, individuals aged $\geq 20$ years are officially considered to be adults)], type of tumor (bone vs. soft tissue tumor) and surgical procedure were also investigated. The surgical procedures were classified as amputation or limb preservation groups at the last follow-up. One patient who had undergone rotationplasty was classified into the amputation group.

Classification by fertility. The fertility of the 47 patients was also investigated. Childbirth was selected as the end-point of fertility, as it was considered important to ascertain whether the offspring, particularly the first-born, of subjects who had received chemotherapy were normal. The proportion of fertile subjects was defined as the number of patients fathering or conceiving offspring/total number of patients. As some patients already had children prior to treatment, the data on fertility at the final follow-up did not represent the true proportion of fertile subjects. To determine the true effect of chemotherapy on fertility, the 'true fertility proportion' was calculated as the difference between the proportion of patients with offspring at presentation and with offspring at the final follow-up. The associations between the proportion of fertile patients and gender (male vs. female), age ( $<20$ vs. $\geq 20$ years), type of tumor (bone vs. soft tissue tumor) and surgical procedure (limb preservation vs. amputation) were investigated.

The interval from the completion of chemotherapy to the first childbirth was considered a marker of fertility recovery. Whether the offspring presented with any problems was also assessed.

As described above, the main drugs used were DOX, CDDP, MTX and IFM (22). The association between fertility and the doses of each of these agents was evaluated.

Statistical analysis. The Fisher's exact probability test was performed for statistical comparison of two groups. Statistical analysis was performed using Excel statistics software, 
Table I. Clinical characteristics of the patients.

\begin{tabular}{|c|c|}
\hline Characteristics & $\begin{array}{c}\text { Patient no. } \\
\quad(n=47)\end{array}$ \\
\hline \multicolumn{2}{|l|}{ Gender } \\
\hline Male & 24 \\
\hline Female & 23 \\
\hline \multicolumn{2}{|l|}{ Type of tumor } \\
\hline Bone & 38 \\
\hline Soft tissue & 9 \\
\hline \multicolumn{2}{|l|}{ Histopathology } \\
\hline Osteosarcoma & 33 \\
\hline Ewing's sarcoma & 4 \\
\hline Synovial sarcoma & 3 \\
\hline MPNST & 1 \\
\hline Epithelioid sarcoma & 1 \\
\hline Myxoid liposarcoma & 1 \\
\hline Leiomyosarcoma & 1 \\
\hline Chondrosarcoma & 1 \\
\hline Extraskeletal Ewing's sarcoma & 1 \\
\hline Extraskeletal osteosarcoma & 1 \\
\hline \multicolumn{2}{|l|}{ Site of primary tumor } \\
\hline \multicolumn{2}{|l|}{ Bone } \\
\hline Femur & 16 \\
\hline Tibia & 11 \\
\hline Humerus & 4 \\
\hline Pelvis & 3 \\
\hline Ulna & 1 \\
\hline Fibula & 1 \\
\hline Radius & 1 \\
\hline Phalanx & 1 \\
\hline \multicolumn{2}{|l|}{ Soft tissue } \\
\hline Thigh & 6 \\
\hline Upper arm & 2 \\
\hline Retroperitoneum & 1 \\
\hline \multicolumn{2}{|l|}{ State of affected limb } \\
\hline Limb preservation & 41 \\
\hline Amputation & 5 \\
\hline Rotationplasty & 1 \\
\hline
\end{tabular}

MPNST, malignant peripheral nerve sheath tumor.

version 2012 (Social Survey Research Information Co., Ltd., Tokyo, Japan) for Windows. $\mathrm{P}<0.05$ was considered to indicate a statistically significant difference.

\section{Results}

Patients. The relevant clinical characteristics of the patients, including gender, type of tumor, histopathology, site of primary tumor and state of affected limb are summarized in Table I.
Table II. Effect of treatment on marriage.

\begin{tabular}{|c|c|c|c|c|}
\hline \multirow[b]{2}{*}{ Variables } & \multicolumn{2}{|c|}{$\begin{array}{l}\text { Marriage } \\
\text { proportion }\end{array}$} & \multirow{2}{*}{$\begin{array}{c}\text { True } \\
\text { marriage } \\
\text { proportion }\end{array}$} & \multirow[b]{2}{*}{ P-value } \\
\hline & Initial & Final & & \\
\hline Gender & & & & 0.093 \\
\hline Male & $4 / 24$ & $7 / 24$ & $3 / 24$ & \\
\hline Female & $2 / 23$ & $10 / 23$ & $8 / 23$ & \\
\hline $\begin{array}{l}\text { Age at diagnosis, } \\
\text { years }\end{array}$ & & & & 0.741 \\
\hline$<20$ & $0 / 24$ & $5 / 24$ & $5 / 24$ & \\
\hline$\geq 20$ & $6 / 23$ & $12 / 23$ & $6 / 23$ & \\
\hline Type of tumor & & & & 0.925 \\
\hline Bone & $5 / 38$ & $14 / 38$ & $9 / 38$ & \\
\hline Soft tissue & $1 / 9$ & $3 / 9$ & $2 / 9$ & \\
\hline Surgery & & & & 0.676 \\
\hline Limb-preserving & $5 / 41$ & $15 / 41$ & $10 / 41$ & \\
\hline Amputation & $1 / 6$ & $2 / 6$ & $1 / 6$ & \\
\hline
\end{tabular}

Table III. Effect of treatment on fertility.

\begin{tabular}{lcccc}
\hline & \multicolumn{2}{c}{$\begin{array}{c}\text { Fertility } \\
\text { proportion }\end{array}$} & & \\
\cline { 2 - 3 } Variables & Initial & Final & $\begin{array}{c}\text { True fertility } \\
\text { proportion }\end{array}$ & P-value \\
\hline Gender & & & & 0.036 \\
Male & $2 / 24$ & $4 / 24$ & $2 / 24$ & \\
Female & $2 / 23$ & $10 / 23$ & $8 / 23$ & \\
Age at diagnosis, & & & & 0.723 \\
years & & & & \\
$\quad<20$ & $0 / 24$ & $4 / 24$ & $4 / 24$ & \\
$\geq 20$ & $4 / 23$ & $10 / 23$ & $6 / 23$ & \\
Type of tumor & & & & 0.938 \\
Bone & $3 / 38$ & $11 / 38$ & $8 / 38$ & \\
$\quad$ Soft tissue & $1 / 9$ & $3 / 9$ & $2 / 9$ & \\
Surgery & & & & 0.767 \\
Limb-preserving & $3 / 41$ & $12 / 41$ & $9 / 41$ & \\
Amputation & $1 / 6$ & $2 / 6$ & $1 / 6$ & \\
\hline
\end{tabular}

Effect of treatment on marriage. The overall proportion of patients who were married prior to treatment was 6/47 (12.8\%) and at the final follow-up $17 / 47$ (36.2\%); thus, the true marriage proportion was $23.4 \%$ (11/47). There were no significant associations between marital status and gender $(\mathrm{P}=0.093)$, age $(\mathrm{P}=0.741)$, type of tumor $(\mathrm{P}=0.925)$, or surgical procedure $(\mathrm{P}=0.676)$ (Table II).

Effect of treatment on fertility. The overall initial proportion of fertile subjects was $4 / 47$ (8.5\%); this had increased to $14 / 47$ $(29.8 \%)$ by the time of the final follow-up. Thus, the true proportion of fertile subjects at the final follow-up was $21.3 \%$ 
Table IV. Clinical data concerning first offspring.

\begin{tabular}{|c|c|c|c|c|c|c|c|c|}
\hline $\begin{array}{l}\text { Case } \\
\text { no. }\end{array}$ & $\begin{array}{l}\text { Age at } \\
\text { diagnosis, } \\
\text { years }\end{array}$ & $\begin{array}{l}\text { Patient } \\
\text { gender }\end{array}$ & Histopathology & $\begin{array}{l}\text { Age at } \\
\text { delivery, } \\
\text { years }\end{array}$ & $\begin{array}{l}\text { Gender } \\
\text { of first } \\
\text { offspring }\end{array}$ & $\begin{array}{c}\text { First } \\
\text { delivery }\end{array}$ & $\begin{array}{l}\text { Congenital } \\
\text { deformities }\end{array}$ & $\begin{array}{c}\text { Other } \\
\text { offsprings }\end{array}$ \\
\hline 1 & 30 & M & Osteosarcoma & 32 & $\mathrm{M}_{\mathrm{o}}$ & Transvaginal delivery & None & \\
\hline 2 & 17 & M & Osteosarcoma & 25 & $\mathrm{M}_{\mathrm{o}}$ & Transvaginal delivery & None & Two $\mathrm{M}_{\mathrm{o}}$ \\
\hline 3 & 23 & $\mathrm{~F}$ & Synovial sarcoma & 32 & $\mathrm{~F}_{\mathrm{o}}$ & $\begin{array}{l}\text { Caesarean section } \\
\text { medical termination } \\
30 \mathrm{w}(\mathrm{BW} 1,570 \mathrm{~g})\end{array}$ & None & \\
\hline 4 & 26 & $\mathrm{~F}$ & Osteosarcoma & 30 & $\mathrm{M}_{\mathrm{o}}$ & Transvaginal delivery & None & \\
\hline 5 & 14 & $\mathrm{~F}$ & Osteosarcoma & 26 & $\mathrm{~F}_{\mathrm{o}}$ & $\begin{array}{l}\text { Caesarean section } \\
\text { (infected amniotic } \\
\text { fluid, myoma uteri) } \\
38 \text { w (BW 2,250 g) }\end{array}$ & None & \\
\hline 6 & 22 & $\mathrm{~F}$ & Osteosarcoma & 33 & $\mathrm{~F}_{\mathrm{o}}$ & $\begin{array}{l}\text { Caesarean section } \\
\text { (abnormal rotation } \\
\text { of fetus) } \\
42 \mathrm{w}(\mathrm{BW} 3,240 \mathrm{~g})\end{array}$ & None & \\
\hline 7 & 17 & $\mathrm{~F}$ & Osteosarcoma & 34 & $\mathrm{~F}_{\mathrm{o}}$ & Transvaginal delivery & None & $\mathrm{F}_{\mathrm{o}}$ \\
\hline 8 & 21 & $\mathrm{~F}$ & Synovial sarcoma & 25 & $\mathrm{M}_{\mathrm{o}}$ & Transvaginal delivery & None & $\begin{array}{c}\mathrm{F}_{\mathrm{o}} \\
\text { (Premature } \\
\text { birth } 35 \mathrm{w} \text { ) }\end{array}$ \\
\hline 9 & 23 & $\mathrm{~F}$ & Osteosarcoma & 35 & $\mathrm{~F}_{\mathrm{o}}$ & Transvaginal delivery & None & $\mathrm{M}_{\mathrm{o}}$ \\
\hline 10 & 13 & $\mathrm{~F}$ & Osteosarcoma & 40 & $\mathrm{~F}_{\mathrm{o}}$ & $\begin{array}{l}\text { Caesarean section } \\
\text { (abnormal rotation } \\
\text { of fetus) } \\
39 \mathrm{w}(\mathrm{BW} 3,345 \mathrm{~g})\end{array}$ & None & \\
\hline
\end{tabular}

M, male; F, female; $M_{0}$, male offspring; $F_{0}$, female offspring; w, weeks; BW, body weight.

(10/47). The true proportion of fertile subjects was significantly associated with gender $(\mathrm{P}=0.036)$, but not with age $(\mathrm{P}=0.723)$, type of tumor $(\mathrm{P}=0.938)$, or surgical procedure $(\mathrm{P}=0.767)$. The true proportion of fertile subjects was significantly lower in men compared to that in women (Table III).

Interval from last chemotherapy to delivery of first offspring. The overall median interval from the completion of chemotherapy to the delivery of the first offspring was 9.5 years (range, 1-27 years). The wife of one of the two fertile men delivered their first offspring 2 years after the patient's last chemotherapy and the wife of the other patient 7 years after his last chemotherapy. The mean interval between the last chemotherapy and delivery was 11.5 years in the 8 fertile women, with the shortest interval being 1.0 year (Fig. 1).

Clinical data regarding the first childbirth following chemotherapy. The clinical data regarding the first childbirth following treatment of high-grade bone and soft tissue tumors is summarized in Table IV. At the last follow-up, 10 patients had a total of 15 offspring after treatment. Of these 10 subjects, 8 had osteosarcomas and the remaining 2 synovial sarcomas. Seven of the offspring were male and 8 were female. Of the first offspring, 4 were male and 6 were female. Six of the first offspring were delivered transvaginally and 4 by caesarean sections. One female patient (case 3), who

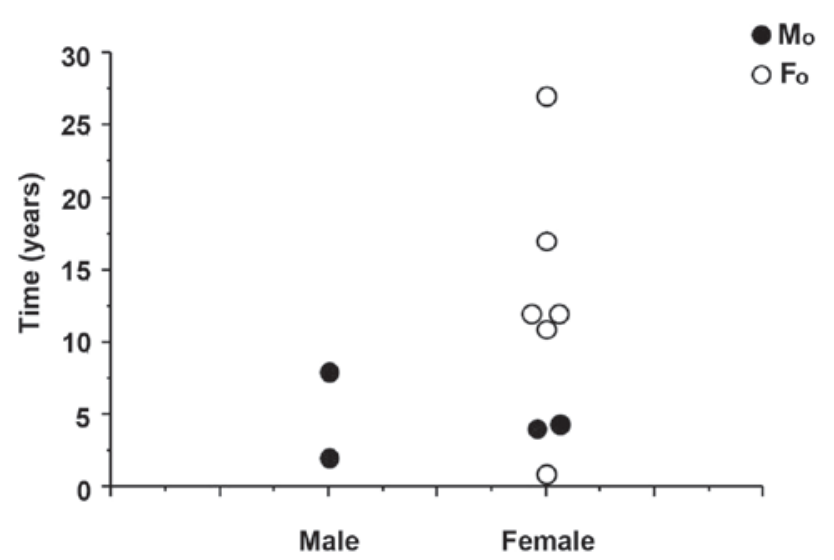

Figure 1. Interval between last chemotherapy and first delivery. The wives of the 2 fertile men delivered their first offspring at 2 and 7 years after completion of the chemotherapy. In the 8 fertile women, the mean interval to delivery was 11.5 years. $M_{0}$, male offspring; $F_{o}$, female offspring.

had synovial sarcoma and later conceived, was diagnosed with lung metastases during her pregnancy and underwent medical termination of the pregnancy; the fetus had a birth weight of $1,570 \mathrm{~g}$ and no congenital deformities. In case 5, a uterine myoma was detected during pregnancy and infection of the amniotic fluid necessitated urgent delivery by caesarean 


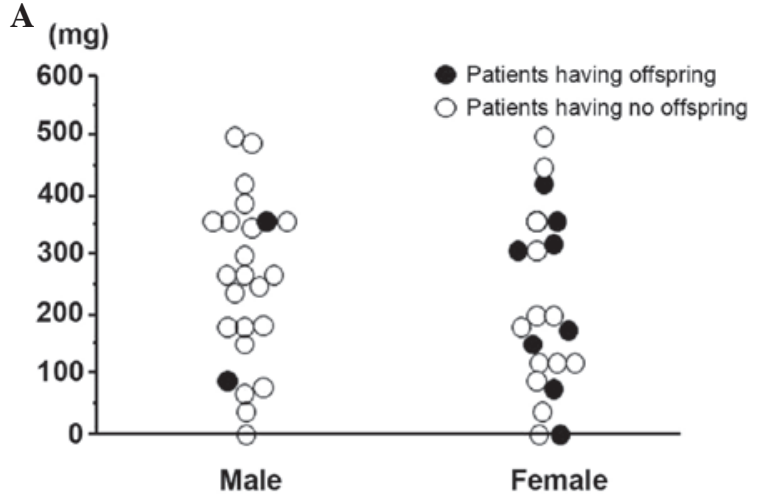

C (g)

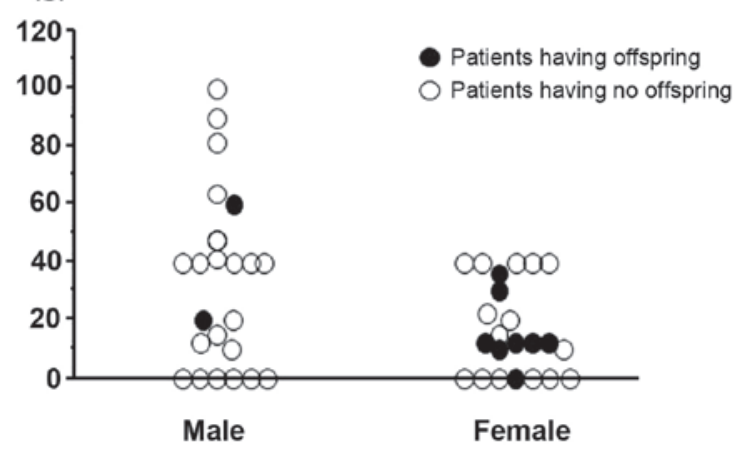

B

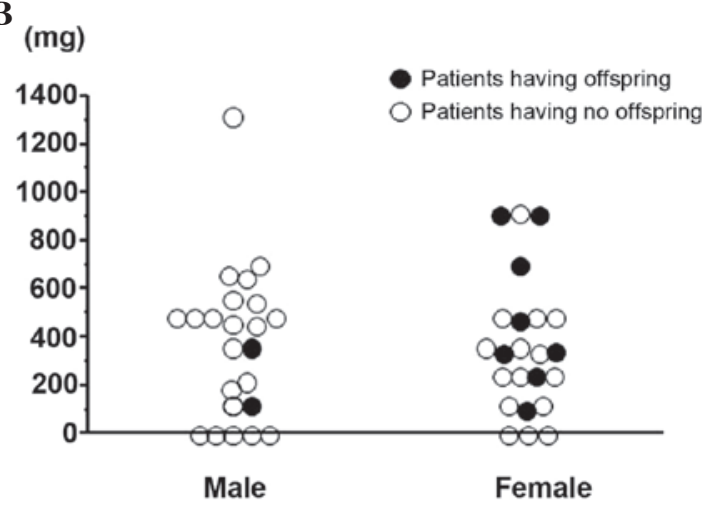

D

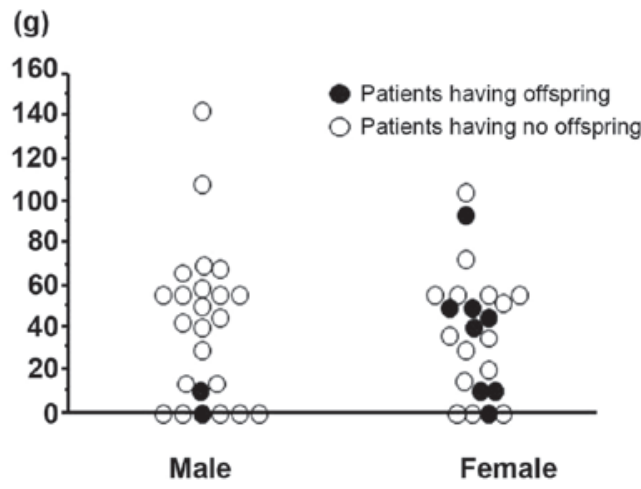

Figure 2. Association between cumulative dose of each chemotherapeutic agent and subsequent childbirth. (A) Total dose of doxorubicin and childbirth. (B) Total dose of cisplatin and childbirth. (C) Total dose of methotrexate and childbirth. (D) Total dose of ifosfamide and childbirth.

section. In cases 6 and 10, caesarean sections were required due to prolonged labor caused by abnormal rotation of the fetus. None of the 15 offspring conceived after their parents had received chemotherapy had congenital deformities. Case 10 had received hormone therapy to induce pregnancy and delivered her first offspring at the age of 40 years, which was 27 years after her cancer treatment.

Association between cumulative dose of each chemotherapeutic agent and childbirth. The associations between the birth of the first offspring and total cumulative dose of the drugs DOX, CDDP, MTX and IFM are shown in Fig. 2A-D. Fertile male subjects had received smaller doses, particularly of IFM, compared to those who had not fathered any offspring. Conversely, there was no identified association between childbirth and cumulative doses of chemotherapeutic agents in the female subjects.

\section{Discussion}

In the present study, the overall proportion of married subjects of $36.2 \%$ (17/47) was lower compared to the $63.0 \%$ reported in equivalent subjects in Japan in 2009 (15). These data may reflect the current downturn in the marriage rate in Japan (23). In the present study, the proportion of married men $(31.4 \%$; $7 / 24)$ tended to be lower compared to that of married women (43.4\%; 10/23); however, this difference was not statistically significant $(\mathrm{P}=0.093)$. The treatment for malignant bone and soft tissue tumors may exert a negative effect on the marriage prospects of men. Traditionally, Japanese men are mainly responsible for the financial support to the family; young men (mean age, 33 years at the final follow-up) with a certain impairment of physical function following tumor surgery may consider it inappropriate to start a family, particularly considering the recent economical recession affecting Japan.

Regarding fertility, the overall final proportion and the true proportion of fertile subjects at the last follow-up were $29.8 \%(14 / 47)$ and $21.3 \%$ (10/47), respectively, compared to previous studies that reported $8.3 \%$ in male subjects alone (12) and $41.6 \%(15 / 36)(13)$ and $27.4 \%(17 / 62)$ in both genders (15) (Table V). The total fertility rate in Japan is currently lower compared to that in other developed countries. According to data on women in Japan (23), the live birth rate (number of births/total number of women) is $\sim 75.2 \%$ among Japanese women of similar age. In the present study, 23 women had 13 offspring at the final follow-up; thus, the live birth rate was $56.6 \%$ (13/23). Therefore, chemotherapy for high-grade bone and soft tissue tumor apparently exerts a somewhat negative effect on fertility; however, a statistical analysis of these data is not possible.

The true male fertility rate of $8.3 \%(2 / 24)$ was significantly lower compared to the female fertility rate of $34.8 \%$ $(8 / 23)$. Thus, intensive chemotherapy for malignant bone and soft tissue tumor exerts a more significant negative effect on male compared to female fertility. The two men who fathered offspring had received lower cumulative doses of IFM compared to those who had not (Fig. 2). In 1948, Spitz (24) was the first to report the effects of chemotherapeutic agents on the gonads. Fertility-related problems following chemotherapy, including male azoospermia and female amenorrhea, have been well documented. However, several researchers have reported that chemotherapy for high-grade malignant 
Table V. Comparison of our findings and those of previous reports concerning fertility.

\begin{tabular}{|c|c|c|c|c|c|c|c|c|c|c|c|}
\hline $\begin{array}{l}\text { First } \\
\text { author } \\
\text { (year) }\end{array}$ & Histology & $\begin{array}{c}\text { Mean age }^{\mathrm{a}}, \\
\text { years } \\
\text { (range) }\end{array}$ & Gender & No. & $\begin{array}{l}\text { Patients } \\
\text { with } \\
\text { marriage }\end{array}$ & $\begin{array}{c}\text { Patients } \\
\text { with } \\
\text { offspr. }\end{array}$ & $\begin{array}{c}\text { Total } \\
\text { offspr. } \\
\text { no. }\end{array}$ & $\begin{array}{c}\text { Mean } \\
\text { follow-up }\end{array}$ & $\begin{array}{c}\text { Delivery } \\
\text { outcome } \\
\text { (no.) }\end{array}$ & $\begin{array}{l}\text { Congenital } \\
\text { deformities }\end{array}$ & Refs. \\
\hline $\begin{array}{l}\text { Longhi } \\
\text { (2003) }\end{array}$ & Osteosarcoma & $\begin{array}{c}17 \\
(10-42)\end{array}$ & M & 96 & 26 & 8 & 12 & 9 years & Abortion (1) & None & (12) \\
\hline $\begin{array}{l}\text { Hosalkar } \\
\text { (2004) }\end{array}$ & $\begin{array}{l}\text { Osteosarcoma } \\
\text { Ewing's } \\
\text { sarcoma }\end{array}$ & $\begin{array}{c}18 \\
(12-26)\end{array}$ & $\mathrm{M}, \mathrm{F}$ & 36 & NA & 15 & 24 & $\begin{array}{l}5.5 \text { years } \\
\text { (mean) }\end{array}$ & $\begin{array}{l}\text { Medical } \\
\text { termination (1) } \\
\text { Cesarean } \\
\text { section } \\
\text { (Twin) (1) } \\
\text { Miscarriage (1) }\end{array}$ & None & (13) \\
\hline $\begin{array}{l}\text { Yonemoto } \\
\text { (2003) }\end{array}$ & Osteosarcoma & $\begin{array}{c}16.0 \\
(6-30)\end{array}$ & $\begin{array}{l}\mathrm{M} \\
\mathrm{F}\end{array}$ & $\begin{array}{l}24 \\
21\end{array}$ & $\begin{array}{c}5 \\
16\end{array}$ & $\begin{array}{c}4 \\
12\end{array}$ & 18 & $\begin{array}{c}176.6 \\
\text { months } \\
\text { (average) }\end{array}$ & $\begin{array}{l}\text { Cesarean } \\
\text { section (5) } \\
\text { Abortion (2) }\end{array}$ & None & (14) \\
\hline $\begin{array}{l}\text { Present } \\
\text { study }\end{array}$ & $\begin{array}{l}\text { Sarcoma } \\
\text { (33 osteo- } \\
\text { sarcoma) }\end{array}$ & $\begin{array}{c}18 \\
(4-40)\end{array}$ & $\begin{array}{l}\mathrm{M} \\
\mathrm{F}\end{array}$ & $\begin{array}{l}24 \\
23\end{array}$ & $\begin{array}{l}7 \\
8\end{array}$ & $\begin{array}{l}4 \\
8\end{array}$ & 15 & $\begin{array}{c}11.0 \text { years } \\
\text { (mean) }\end{array}$ & $\begin{array}{l}\text { Cesarean } \\
\text { section (3) } \\
\text { Medical } \\
\text { termination (1) }\end{array}$ & None & \\
\hline
\end{tabular}

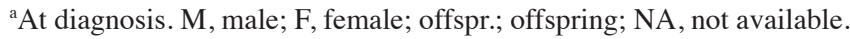

bone tumors does not affect the fertility rate $(13,14)$. Recently, however, more intensive chemotherapy has been used for high-grade bone tumors, with a resultant increase in the number of long-term survivors. The sequelae of this more intensive chemotherapy scheme have been re-evaluated and found to negatively affect fertility in male long-term cancer survivors $(12,15)$. The chemotherapeutic dose has been associated with damage to the gonads (25). The cumulative dose of chemotherapeutic agents was the most significant determinant, largely due to only few patients receiving single-agent chemotherapy, as multiple-drug chemotherapy is widespread and highly effective. DOX, CDDP, MTX and IFM are the key chemotherapeutic drugs used to treat high-grade bone and soft tissue tumors. Among chemotherapeutic drugs, it has been demonstrated that alkylating agents are the most toxic to the gonads $(26,27)$. Longhi et al (12) reported that 20/26 male patients exhibited oligospermia or azoospermia following chemotherapy with high-dose IFM (median, $42 \mathrm{~g} / \mathrm{m}^{2}$ ) for osteosarcoma. Williams et al (28) reported that gonadal dysfunction occurs after total IFM doses of $>60 \mathrm{~g} / \mathrm{m}^{2}$. Longhi et al (29) reported that patient age and dose of alkylating agent are the most significant predictors of early menopause in young female patients with osteosarcoma. Meistrich et al (30) reported that high-dose CDDP $\left(\geq 600 \mathrm{mg} / \mathrm{m}^{2}\right)$ permanently reduces sperm counts in male patients, whereas according to Wallace et al (31), total doses of CDDP $\geq 490 \mathrm{mg} / \mathrm{m}^{2}$ compromise gonadal function. MTX causes transient testicular dysfunction, but not ovarian dysfunction (32). By contrast, DOX is rarely associated with gonadal toxicity (33).

In our study, the mean interval between the last chemotherapy and the first delivery was 9.5 years (1-14 years), which is similar to previously reported findings $(13,14)$. The shortest interval to first delivery was only 1 year in a female patient (case 3; Table IV). Of note, in that patient, the cumulative doses of chemotherapeutic agents prior to delivery were as follows: DOX, $420 \mathrm{mg} / \mathrm{m}^{2}$; CDDP, $100 \mathrm{mg} / \mathrm{m}^{2}$; IFM, $105 \mathrm{~g} / \mathrm{m}^{2}$; and MTX, $10 \mathrm{~g} / \mathrm{m}^{2}$. Four months after the completion of chemotherapy, the patient conceived; the fetus was delivered by caesarean section. This suggests that female fertility is relatively resistant to the damaging effects of intensive chemotherapy or that there is rapid recovery following completion of chemotherapy.

Patients, particularly female patients, of childbearing age often desire a pregnancy after completing treatment for high-grade bone and soft tissue sarcoma, as they have not yet had the planned number of offspring. As regards the recommendations of health providers and oncologists to such patients regarding the minimal interval between cancer treatment and attempting conception, there are no available published studies for patients with high-grade malignant bone and soft tissue tumors. The Royal College of Obstetricians and Gynaecologists (34) currently recommends that women with breast cancer delay pregnancy for $\geq 2$ years after the diagnosis, as most recurrences occur within this time range. Similarly, the Society of Obstetricians and Gynaecologists of Canada (35) advises women with breast cancer to defer pregnancy for 3 years. The guidelines for soft tissue sarcoma published by the European Society of Medical Oncology (36) recommend that patients with high-grade tumors who have been treated surgically should be followed up every 4 months for the first 2-3 years, this being the period during which relapse usually occurs. Therefore, the minimum recommended interval between pregnancy and last chemotherapy should be 2-3 years.

In the present study, only few subjects experienced complications during delivery (Table IV). A total of 4 patients (40\%) underwent caesarean sections: One for medical termination as the patient had developed lung metastases; one for infected 
amniotic fluid caused by a uterine myoma; and the remaining 2 patients due to prolonged labor caused by abnormal rotation of the fetus. Uterine myomas are common benign gynecological tumors, with an incidence of $\sim 20 \%$. The tumor size is affected by estrogen concentrations; this tumor is unrelated to previous chemotherapy. The incidence of caesarean sections is similar to that previously reported (Table V). The remaining 6 infants were delivered uneventfully (normal transvaginal delivery). Thus, uterine exposure to chemotherapeutic agents for high-grade bone and soft tissue tumors apparently exerts no negative effect on childbirth.

Another concern regarding sarcoma treatment is that any offspring may be at increased risk of congenital deformities (7). As chemotherapeutic agents are potential mutagens, there is a theoretical risk of chemotherapy increasing the incidence of congenital deformities and miscarriage. A previous review (37) concluded that the overall incidence of congenital malformations following cancer treatment is $3-4 \%$, which is similar to the incidence in the general population. In the present study, no congenital deformities were detected in any of the offspring of subjects who had received intensive chemotherapy (Table IV). Thus, intensive chemotherapy for high-grade bone and soft tissue tumors exerted no detectable effect on the offspring of our patients.

This study has certain limitations, namely its retrospective design, limited patient sample, lack of control cases and the fact that it was conducted in a single Japanese institution. Moreover, we collected limited clinical information regarding the pregnancies and used delivery as the endpoint for functional assessment of fertility. It would have been preferable to investigate variables associated with the menstrual cycle in our female subjects and to perform semen analysis in the men. In addition, measurements of the serum concentrations of sex-related hormones, such as follicle-stimulating hormone, luteinizing hormone and testosterone (38), would have provided more objective indicators of fertility, as would the radiological assessment of the size of the testes or ovaries (39). However, high-grade bone and soft tissue tumors are rare and data on pregnancies are extremely difficult to obtain, as there are so few long-term survivors. Finally, as these patients had been administered various chemotherapeutic agents under different protocols, we were unable to accurately identify the effect of any single agent on gonadal function.

The 2006 American Society of Clinical Oncology clinical practice guidelines (40), updated in 2012 (41), recommend that health care providers, including oncologists, discuss the possibility of infertility and other potential risks with patients who are scheduled to receive chemotherapy during their reproductive years prior to the administration of any treatment. All the patients should understand the possible risk of infertility following chemotherapy. Our institution has a standard practice of offering sperm, embryo and oocyte cryopreservation prior to treatment initiation.

In conclusion, intensive chemotherapy for high-grade bone and soft tissue tumors may compromise the fertility of young patients, particularly men. However, there is no evidence for the offspring of such patients being at increased risk of congenital deformities. All young patients with high-grade bone and soft tissue tumors receive counseling regarding the possibility of infertility prior to the initiation of chemotherapy.

\section{Acknowledgements}

We would like to thank Daisuke Tachibana for obstetric assistance during the deliveries and interpretation of our data.

\section{References}

1. Meyers PA, Heller G, Healey J, Huvos A, Lane J, Marcove R, Applewhite A, Vlamis V and Rosen G: Chemotherapy for nonmetastatic osteogenic sarcoma: the Memorial Sloan-Kettering experience. J Clin Oncol 10: 5-15, 1992.

2. Meyers PA, Gorlick R, Heller G, Casper E, Lane J, Huvos AG and Healey JH: Intensification of preoperative chemotherapy for osteogenic sarcoma: results of the Memorial Sloan-Kettering (T12) protocol. J Clin Oncol 16: 2452-2458, 1998.

3. Yang JC, Chang AE, Baker AR, Sindelar WF, Danforth DN, Topalian SL, DeLaney T, Glatstein E, Steinberg SM, Merino MJ and Rosenberg SA: Randomized prospective study of the benefit of adjuvant radiation therapy in the treatment of soft tissue sarcomas of the extremity. J Clin Oncol 16: 197-203, 1998.

4. Enneking WF, Spanier SS and Goodman MA: A system for the surgical staging of musculoskeletal sarcoma. Clin Orthop Relat Res 153: 106-120, 1980

5. Kawaguchi N, Ahmed AR, Matsumoto S, Manabe J and Matsushita Y: The concept of curative margin in surgery for bone and soft tissue sarcoma. Clin Orthop Relat Res 419: 165-172, 2004.

6. Longhi A, Ferrari S, Tamburini A, Luksch R, Fagioli F, Bacci G and Ferrari C: Late effects of chemotherapy and radiotherapy in osteosarcoma and Ewing sarcoma patients: the Italian Sarcoma Group Experience (1983-2006). Cancer 118: 5050-5059, 2012.

7. Schover LR, Rybicki LA, Martin BA and Bringelsen KA: Having children after cancer. A pilot survey of survivors' attitudes and experiences. Cancer 86: 697-709, 1999.

8. Nagarajan R, Neglia JP, Clohisy DR, Yasui Y, Greenberg M, Hudson M, Zevon MA, Tersak JM, Ablin A and Robison LL: Education, employment, insurance, and marital status among 694 survivors of pediatric lower extremity bone tumors: a report from the childhood cancer survivor study. Cancer 97: 2554-2564, 2003.

9. Drasga RE, Einhorn LH, Williams SD, Patel DN and Stevens EE: Fertility after chemotherapy for testicular cancer. J Clin Oncol 1: 179-183, 1983.

10. Pryzant RM, Meistrich ML, Wilson G, Brown B and McLaughlin P: Long-term reduction in sperm count after chemotherapy with and without radiation therapy for non-Hodgkin's lymphomas. J Clin Oncol 11: 239-247, 1993.

11. Reichman BS and Green KB: Breast cancer in young women: effect of chemotherapy on ovarian function, fertility, and birth defects. J Natl Cancer Inst Monogr 16: 125-129, 1994.

12. Longhi A, Macchiagodena M, Vitali G and Bacci G: Fertility in male patients treated with neoadjuvant chemotherapy for osteosarcoma. J Pediatr Hematol Oncol 25: 292-296, 2003.

13. Hosalkar HS, Henderson KM, Weiss A, Donthineni R and Lackman RD: Chemotherapy for bone sarcoma does not affect fertility rates or childbirth. Clin Orthop Relat Res 428: 256-260, 2004.

14. Yonemoto T, Tatezaki S, Ishii T and Hagiwara Y: Marriage and fertility in long-term survivors of high grade osteosarcoma. Am J Clin Oncol 26: 513-516, 2003.

15. Yonemoto T, Ishii T, Takeuchi Y, Hagiwara $Y$, Iwata $S$ and Tatezaki S: Recently intensified chemotherapy for high-grade osteosarcoma may affect fertility in long-term male survivors. Anticancer Res 29: 763-767, 2009.

16. Ishida $\mathrm{T}$ and Takami M: Evaluation of chemotherapy before limb-sparing surgery for osteosarcoma. Int Orthop 16: 59-61, 1992.

17. Kudawara I, Aoki Y, Ueda T, Araki N, Naka N, Nakanishi H, Matsumine A, Ieguchi M, Mori S, Myoui A, Kuratsu S, Hashimoto $\mathrm{N}$ and Yoshikawa $\mathrm{H}$ : Neoadjuvant and adjuvant chemotherapy with high-dose ifosfamide, doxorubicin, cisplatin and high-dose methotrexate in non-metastatic osteosarcoma of the extremities: a phase II trial in Japan. J Chemother 25: 41-48, 2013.

18. Tsuchiya $\mathrm{H}$, Tomita $\mathrm{K}$, Mori $\mathrm{Y}$, Asada $\mathrm{N}$ and Yamamoto $\mathrm{N}$ : Marginal excision for osteosarcoma with caffeine assisted chemotherapy. Clin Orthop Relat Res 358: 27-35, 1999. 
19. Juergens C, Weston C, Lewis I, Whelan J, Paulussen M, Oberlin O, Michon J, Zoubek A, Juergens H and Craft A: Safety assessment of intensive induction with vincristine, ifosfamide, doxorubicin, and etoposide (VIDE) in the treatment of Ewing tumors in the EURO-E.W.I.N.G. 99 clinical trial. Pediatr Blood Cancer 47: 22-29, 2006.

20. Tanaka K, Kawamoto H, Saito I, Yoshimura K, Fukuda H and Iwamoto Y: Preoperative and postoperative chemotherapy with ifosfamide and adriamycin for adult high-grade soft-tissue sarcomas in the extremities: Japan Clinical Oncology Group Study JCOG0304. Jpn J Clin Oncol 39: 271-273, 2009.

21. Van Winkle P, Angiolillo A, Krailo M, Cheung YK, Anderson B, Davenport V, Reaman G and Cairo MS: Ifosfamide, carboplatin, and etoposide (ICE) reinduction chemotherapy in a large cohort of children and adolescents with recurrent/refractory sarcoma: the Children's Cancer Group (CCG) experience. Pediatr Blood Cancer 44: 338-347, 2005.

22. Byrne J, Mulvihill JJ, Myers MH, et al: Effects of treatment on fertility in long-term survivors of childhood or adolescent cancer. N Engl J Med 317: 1315-1321, 1987.

23. 2013 Statistics of the Ministry of Health, Labor and Welfare of Japan: Marriage, Childbirth Childrearing, Natality. http:// www.mhlw.go.jp/toukei/youran/index-kourou.html. Accessed January 30, 2014.

24. Spitz S: The histological effects of nitrogen mustards on human tumors and tissues. Cancer 1: 383-398, 1948

25. Bacci G, Ferrari S, Bertoni F, Ruggieri P, Picci P, Longhi A, Casadei R, Fabbri N, Forni C, Versari M and Campanacci M: Long-term outcome for patients with nonmetastatic osteosarcoma of the extremity treated at the Istituto Ortopedico Rizzoli according to the Istituto Ortopedico Rizzoli/osteosarcoma-2 protocol: an updated report. J Clin Oncol 18: 4016-4027, 2000.

26. Kenney LB, Laufer MR, Grant FD, Grier H and Diller L: High risk of infertility and long term gonadal damage in males treated with high dose cyclophosphamide for sarcoma during childhood. Cancer 91: 613-621, 2001.

27. Meistrich ML, Wilson G, Brown BW, da Cunha MF and Lipshultz LI: Impact of cyclophosphamide on long-term reduction in sperm count in men treated with combination chemotherapy for Ewing and soft tissue sarcomas. Cancer 70: 2703-2712, 1992

28. Williams D, Crofton PM and Levitt G: Does ifosfamide affect gonadal function? Pediatr Blood Cancer 50: 347-351, 2008.

29. Longhi A, Pignotti E, Versari M, Asta S and Bacci G: Effect of oral contraceptive on ovarian function in young females undergoing neoadjuvant chemotherapy treatment for osteosarcoma. Oncol Rep 10: 151-155, 2003.
30. Meistrich ML, Chawla SP, Da Cunha MF, Johnson SL, Plager C, Papadopoulos NE, Lipshultz LI and Benjamin RS: Recovery of sperm production after chemotherapy for osteosarcoma. Cancer 63: 2115-2123, 1989.

31. Wallace WH, Shalet SM, Crowne EC, Morris-Jones PH, Gattamaneni HR and Price DA: Gonadal dysfunction due to cis-platinum. Med Pediatr Oncol 17: 409-413, 1989.

32. Shamberger RC, Rosenberg SA, Seipp CA and Sherins RJ: Effects of high-dose methotrexate and vincristine on ovarian and testicular functions in patients undergoing postoperative adjuvant treatment of osteosarcoma. Cancer Treat Rep 65: 739-746, 1981.

33. Waxman J: Chemotherapy and the adult gonad: a review. J R Soc Med 76: 144-148, 1983.

34. Royal College of Obstetricians and Gynaecologists: Pregnancy and Breast Cancer (Green-top Guideline No. 12). http://www. rcog.org.uk/guidelines. Accessed January 27, 2014.

35. Helewa M, Lévesque P, Provencher D, Lea RH, Rosolowich V and Shapiro HM; Breast Disease Committee and Executive Committeee and Council, Society of Obstetricians and Gynaecologists of Canada: Breast cancer, pregnancy, and breastfeeding. J Obstet Gynaecol Can 24: 164-184, 2002 (In English, French).

36. ESMO/European Sarcoma Network Working Group: Soft tissue and visceral sarcomas: ESMO Clinical Practice Guidelines for diagnosis, treatment and follow-up. Ann Oncol 23 (Suppl 7): vii92-vii99, 2012.

37. Nicholson HS and Byrne J: Fertility and pregnancy after treatment for cancer during childhood or adolescence. Cancer 71 (Suppl 10): 3392-3399, 1993.

38. Shamberger RC, Sherins RJ and Rosenberg SA: The effects of postoperative adjuvant chemotherapy and radiotherapy on testicular function in men undergoing treatment for soft tissue sarcoma. Cancer 47: 2368-2374, 1981.

39. Siimes MA, Elomaa I and Koskimies A: Testicular function after chemotherapy for osteosarcoma. Eur J Cancer 26: 973-975, 1990.

40. Lee SJ, Schover LR, Partridge AH, Patrizio P, Wallace WH, Hagerty K, Beck LN, Brennan LV and Oktay K; American Society of Clinical Oncology: American Society of Clinical Oncology recommendations on fertility preservation in cancer patients. J Clin Oncol 24: 2917-2931, 2006.

41. Loren AW, Mangu PB, Beck LN, Brennan L, Magdalinski AJ, Partridge AH, Quinn G, Wallace WH and Oktay K; American Society of Clinical Oncology: Fertility preservation for patients with cancer: American Society of Clinical Oncology clinical practice guideline update. J Clin Oncol 31: 2500-2510, 2013. 